УДК 378.147:37.091.113-057.212]:004(477)(1-87)

https://doi.org/10.52058/2708-7530-2021-12(18)-536-544

Головко Ольга Сергї̈вна аспірантка кафедри теорії і практики технологічної та професійної освіти, Державний вищий навчальний заклад «Донбаський державний педагогічний університет», вул. Г. Батюка 19, м. Слов'янськ, 84116, тел.: (099) 70-13-20, e-mail: olya.holovko.95@gmail.com, https://orcid.org/0000-0001-8748-2169

\title{
ЗАКОРДОННИЙ ДОСВІД ПІДГОТОВКИ МАЙБУТНІХ МЕНЕДЖЕРІВ ОСВІТИ В УМОВАХ НЕФОРМАЛЬНОЇ ОСВІТИ
}

Анотація. Актуальність вивчення закордонного досвіду підготовки майбутніх менеджерів освіти зумовлена процесами глобалізації та інтернаціоналізації освіти, що вимагають створення єдиного освітнього простору за загальними стандартами та підвищення якості освіти. Роль керівників в цьому процесі $\epsilon$ важливою, оскільки вони $\epsilon$ відповідальними за розвиток закладів освіти та якість тих освітніх послуг, які надає заклад. В європейському освітньому просторі діє низка нормативних документів, які створюють підгрунтя підготовки майбутніх фахівців у сфері управління освітніми закладами. Метою статті є теоретичний аналіз досвіду закордонних країн підготовки майбутніх менеджерів освіти в умовах неформальної освіти. Для досягнення поставленої мети було проаналізовано нормативно-правові документи, що діють на території Свропейського Союзу, у яких наголошено, що керівники закладів освіти мають здійснювати професійну діяльність на основі принципів інституційної автономії та академічної свободи, а їхня професійна підготовка має бути організована за умови інтеграції формальної та неформальної освіти. Аналіз наукових праць вітчизняних та іноземних науковців дозволив встановити, що світовою тенденцією підготовки фахівців у сфері управління закладами освіти є запровадження програм різної тривалості. 3'ясовано, що головною відмінністю неформального навчання від формального $\epsilon$ той факт, що участь в освітніх активностях ініціюється самими здобувачами, серед яких тренінги, інтенсивні курси, воркшопи та інші. Доведено, що більшість таких програм реалізується через запровадження тренінгів, що $є$ актуальною та ефективною формою взаємодії майбутніх фахівців у сфері управління закладами освіти. У ході розвідок встановлено, що серед неформальних цифрових освітніх засобів особливе місце посідають масові відкриті онлайн-курси (МООС-курси).

Ключові слова: менеджер освіти, керівник закладу освіти, неформальна освіта, тренінги, МООС-курси. 
Holovko Olha Serhiivna PhD student of the Department of Theory and Practice of Technological and Vocational Education at State Higher Educational Institution "Donbas State Pedagogical University", 19 H. Batiuka St., Sloviansk, 84116, tel.: (099) 70-13-20, e-mail: olya.holovko.95@gmail.com, https://orcid.org/0000-0001-8748-2169.

\section{FOREIGN EXPERIENCE OF FUTURE EDUCTION MANAGERS' TRAININF IN THE CONDITIONS OF NON-FORMAL EDUCATION}

Abstract. The relevance of studying the foreign experience of future education managers' training is caused by processes of globalisation and internationalisation of education, which require creating a single educational environment within the common standards and improving the quality of education. The role of educational institution leaders in this process is essential because they are responsible for the development of educational institutions and the quality of the educational services provided by the institution. There are a number of normative documents in the European educational space, which create regulatory basis for training future specialists. The purpose of the article is to theoretically analyse the experience of foreign countries in future education managers' training in non-formal education. To achieve this purpose, the regulatory documents, adopted by the European Union, are analysed, which emphasise that educational institution leaders should carry out professional activities, based on the principles of institutional autonomy and academic freedom, and their training should be organised with the integration of formal and non-formal education. The analysis of scientific works of Ukrainian and foreign scientists allows to assert that the world trend of training specialists in the field of managing educational institutions is implemented in the conditions of nonformal education by introducing programs of different duration. It is found out that the main difference between non-formal and formal education is the fact that the participation in educational activities is initiated by students themselves, including trainings, intensive courses, workshops and others. It is proved that most of such programs are implemented through conducting a training program, which is a relevant and effective form of interaction of future professionals in the field of educational institution management. While studying the issue, it is revealed that massive open online courses (MOOC) play an important part among non-formal digital educational tools.

Keywords: education manager, educational institution leader, non-formal education, trainings, massive open online courses.

Постановка проблеми. В умовах реформування системи освіти в України питання підготовки майбутніх менеджерів освіти набуває особливої актуальності, оскільки керівники закладів освіти різних рівнів $\epsilon$ відповідальними за конкурентоспроможність закладу освіти та якість освітніх 
послуг, які надає заклад. Успішна діяльність керівників можлива за умови запровадження сучасних підходів до управління закладами освіти, iз урахуванням сучасних тенденцій інтернаціоналізації та глобалізації, які торкаються і системи освіти. Для модернізації системи професійної підготовки майбутніх менеджерів освіти в Україні важливим є ознайомлення 3 досвідом закордонних країн задля сприяння євроінтеграційним процесам, створення єдиного Європейського освітнього простору, підвищення якості вищої освіти.

На території Європейського Союзу діє ціла низка нормативно-правових документів, що регулюють визначення механізмів забезпечення якості освіти, у цьому процесі важливу роль відіграють керівники закладів освіти, що обгрунтовано в таких документах: Грацька декларація (2003) (Graz declaration «Forward from Berlin: the role of the universities to 2010 and beyond»), Комюніке конференції Міністрів країн Свропи, відповідальних за сферу вищої освіти (2009) (Communiqué of the Conference of European Ministers Responsible for Higher Education), Стратегія Свропи 2020: для розумного, сталого та всеохоплюючого розвитку (2010) (Europe 2020: A Strategy for Smart, Sustainable and Inclusive Growth: Communication from the European Commission) (2010). У цих документах наголошено на необхідності підвищення якості освіти в країнахчленах Європейського Союзу, що має базуватися на наданні автономії закладам освіти, побудові освітнього процесу на демократичних принципах та створенні демократичного освітнього середовища, сприянні розвитку формальної та неформальної освіти.

Аналіз останніх досліджень і публікацій. Вивченню та запровадженню закордонного досвіду підготовки майбутніх керівників закладів освіти присвячено дослідження таких вітчизняних науковців: О. Баніт (закордонний досвід підготовки фахівців в умовах формальної та неформальної освіти); В. Берека (зарубіжні моделі підготовки менеджерів освіти); О. Загребельна (формування управлінської компетентності майбутніх менеджерів освіти в зарубіжних країнах); В. Ткаченко (досвід Сполученого Королівства в підготовці керівників закладів освіти).

Питання розвитку системи неформальної освіти висвітлено в працях I. Гребенюк (формування цифрової компетентності керівників закладів освіти в умовах неформальної освіти), Д. Сотнікова (запровадження масових відкритих онлайн-курсів під час вивчення економічних дисциплін у системі неформальної освіти), О.ХХденка (створення індивідуальної освітньої траєкторії професійного розвитку керівників закладів освіти засобами формальної, неформальної та інформальної освіти).

Аналіз англомовних наукових джерел дозволив встановити, що проблемі підготовки фахівців у сфері управління закладами освіти присвячено наукові розвідки Н. Brower, A. Caza, L. E. Rumbley, J. Mitana, A. Kitawi та ін.

Однак, з-поміж значної кількості досліджень, присвячених різним аспектам підготовки майбутніх керівників закладів освіти, поза увагою 
науковців залишилося питання вивчення закордонного досвіду запровадження засобів неформальної освіти в систему професійної підготовки керівників закладів освіти.

Мета статті полягає в теоретичному аналізі досвіду закордонних країн підготовки майбутніх менеджерів освіти в умовах неформальної освіти.

Виклад основного матеріалу. Питання професійної підготовки менеджерів освіти $є$ актуальним, проте неоднозначним, оскільки, діяльність керівників закладів освіти поєднує в собі дві основні функції - управлінську та педагогічну. Успішне виконання управлінської функції залежить від типу закладу освіти, закономірностей його функціонування та стратегії його розвитку. Педагогічна діяльність керівника вимагає володіння інноваційними технологіями, застосування творчого підходу до організації освітнього процесу в закладі освіти. Тож, вітчизняні науковці (І. Ерсьозоглу, В. Ткаченко) наголошують на необхідності пошуку нових підходів до професійної підготовки майбутніх менеджерів освіти, задля розвитку людського потенціалу та підготовки керівників закладів освіти нового формату, оскільки сфера управління є одним із ключових факторів розвитку системи освіти в цілому та значно впливає на якість освітніх послуг [3].

Проведені наукові розвідки дозволяють стверджувати, що значна увага в закордонних країнах приділена підготовці менеджерів освіти, розробленню іiі нормативно-правового, науково-методичного та інформаційного забезпечення.

Характеризуючи нормативно-правове забезпечення, слід врахувати такі офіційні документи:

1) Грацька декларація (2003) (Graz declaration «Forward from Berlin: the role of the universities to 2010 and beyond»), підписана Европейською Асоціацією університетів, яка визначає, що заклади вищої освіти мають підтримувати високий рівень якості освіти, управління та лідерства через розвиток стратегічного управління [10];

2) У Комюніке конференції Міністрів країн Свропи, відповідальних за сферу вищої освіти (2009) (Communiqué of the Conference of European Ministers Responsible for Higher Education) зазначено, що освітній процес в закладах освіти має базуватися на загальноєвропейських цінностях автономіі, що вимагає повної участі в цьому процесі всіх учасників освітнього процесу [6];

3) Стратегія Свропи 2020: для розумного, сталого та всеохоплюючого розвитку (2010) (Europe 2020: A Strategy for Smart, Sustainable and Inclusive Growth: Communication from the European Commission) (2010) підкреслює важливість визнання формальної та неформальної освіти як одного із напрямів модернізації освіти [7];

4) Програма освіти та навчання Свропейської Комісії (The Education and Training (ET 2020) program of the European Commission) (2009), розроблена для підвищення якості професійної підготовки вчителів та керівників закладів освіти, визначає головну роль керівників у створенні якісного навчального 
середовища закладу, а також у документі наголошено на необхідності надавати менеджерам освіти можливість розвивати їхню управлінську компетентність [13].

Із огляду на проведений аналіз нормативних документів щодо забезпечення якості освіти можна зробити узагальнення, що роль менеджерів освіти $є$ визначальною в цьому процесі. Керівники закладів освіти мають здійснювати професійну діяльність на основі принципів інституційної автономії та академічної свободи, а їхня професійна підготовка має бути організована за умови інтеграції формальної та неформальної освіти.

Наукові узагальнення американської вченої L. E. Rumbley, у яких вона виклала результати двох досліджень, проведених Центром міжнародної вищої освіти Бостонського коледжу (the Boston College Center for International Higher Education (CIHE)) та Міжнародною Асоціацією Університетів (the International Association of Universities (IAU)), дають нам підстави стверджувати, що більшість фахівців у сфері управління закладами освіти в усьому світі отримують підготовку в умовах неформальної освіти, що $\epsilon$ світовою тенденцією. Дослідниця пояснює причини розповсюдження неформальної освіти тим, що сучасна освітня система зазнає значних змін, що спричинені вимогою набувати компетентності та програмні результати навчання відповідно до державних стандартів, запроваджувати інновації в освітній процес. У межах проведення цих досліджень було здійснено пошук освітніх програм підготовки менеджерів освіти й дослідники зазначили, що їх загальна кількість в усіх університетах світу склала менше 120 та запроваджуються вони переважно в країнах з розвиненою економікою [12].

Однак, проаналізоване вище дослідження засвідчує, що є ціла низка програм підготовки в сфері неформальної освіти, що тривають від кількох днів до одного-двох тижнів, реалізуються на платній основі та надають документальне підтвердження навчання за програмою. Такі програми $\epsilon$ вузькопрофільними та орієнтованими на розвиток фахових умінь керівників, а саме: лідерських та підприємницьких умінь, умінь стратегічного планування, комунікативних умінь та ін.

A. Caza та Н. Brower, вивчаючи проблеми формальної та неформальної освіти, наголошують, що неформальні аспекти в підготовці освітніх менеджерів $\epsilon$ надзвичайно важливими, проте їм приділяється недостатньо уваги в освітньому процесі закладів вищої освіти. Так, дослідники говорять, що сучасні освітні програми підготовки фахівців мають обов'язково пропонувати здобувачам брати участь в активностях (тренінги, інтенсивні курси, воркшопи тощо), що проводяться різними організаціями, як освітніми, так і неосвітніми (громадські організації, центри зайнятості тощо). Головною відмінністю неформального навчання від формального $є$ той факт, що участь в активностях ініціюється самими здобувачами [5].

Дослідники B. Trafford i E. Bäckman стверджують, що ефективним методом підготовки менеджерів освіти виступає тренінг, оскільки він 
передбачає групову роботу як основну форму навчальної взаємодії, що дозволяє розвивати управлінську компетентність керівників закладів освіти на демократичних засадах шляхом прийняття спільних рішень та розподілення обов’язків у групі [4].

Задля сприяння входження України до єдиного Свропейського освітнього простору визнання неформальної освіти відбулося на державному рівні, яка потрактована як «освіта, яка здобувається, як правило, за освітніми програмами та не передбачає присудження визнаних державою освітніх кваліфікацій за рівнями освіти, але може завершуватися присвоєнням професійних та/або присудженням часткових освітніх кваліфікацій» [1]. I хоча на основі здобутих компетентностей в неформальній освіті не може відбуватися присудження освітніх кваліфікації, розповсюдженою вітчизняною та іноземною практикою $є$ зарахування результатів навчання, здобутих в неформальній освіті, що обраховуються за певною кількістю годин вивчення навчальної дисципліни. Така практика підтвердження результатів навчання, здобутих в неформальній освіті, має нормативно-правове підгрунтя і $\epsilon$ викладеною в офіційному документі «Свропейські рекомендації щодо підтвердження неформального та інформального навчання» (European guidelines for validating non-formal and informal learning) (2015). У документі наголошено, що неформальна освіта може бути складовою формальної, що надає процесу професійної підготовки в закладах вищої освіти завершеності, або може стати альтернативою до формальної освіти та сприяти особистісному, професійному та соціальному розвитку здобувача [8].

Масовий перехід закладів освіти різних рівнів на дистанційну форму навчання в період пандеміï Covid-19 сприяв розширенню спектру цифрових засобів та ресурсів, що запроваджуються для організації освітнього процесу. Вони класифікуються за різними ознаками, зокрема: за тематичними напрямами, функціональними особливостями, необхідністю залучення програмного забезпечення тощо. Вітчизняні та іноземні науковці одностайні в своїх твердженнях, що серед неформальних цифрових освітніх засобів особливе місце посідають масові відкриті онлайн-курси (МООС-курси). Інтерес для нашого дослідження становлять МООС-курси підготовки менеджерів освіти та аналіз можливостей їх використання саме в сфері неформальної освіти. Слід зазначити, що розроблення та використання МООС-курсів $\epsilon$ світовою тенденцією у сфері як формальної, так і неформальної освіти. Поняття MOОС було вперше введено до вжитку американськими вченими G. Siemens i S. Downes у 2008 р. під час обгрунтування змісту та структури курсу «Конективізм та зв'язні знання» (Connectivism and Connective Knowledge). I3 того часу інтерес наукової спільноти до цих курсів поступово зростав, було проведено низку досліджень задля висвітлення переваг та недоліків їх використання, задля опису головних ознак масових відкритих онлайн-курсів тощо. Найвідомішими в світі платформами, на базі яких реалізуються 
MOOC-курси, є Coursera, edX, Udemy, Udacity, Course Buffet, FutureLearn, Canvas Network, MyEducationKey, MIT OCW, Stanford online, Khan Academy, MIT Open Courseware.

Як доводить аналіз наукових джерел та МООС-платформ запровадження таких курсів $є$ визнаним серед найкращих університетів світу, а саме університети Оксфорда та Кембриджа, Лондонський університет, університети Стенфорда та Гарварда пропонують масові відкриті онлайн-курси різного тематичного спрямування та різної тривалості. Для нашого наукового пошуку важливим $\epsilon$ аналіз наявних МООС-курсів, зокрема їхньої тематики, що можуть бути використані в процесі професійної підготовки майбутніх менеджерів освіти. Робота з пошуковими системами MOOC-платформ Coursera, edX, FutureLearn та Canvas.net дозволила встановити кількість розроблених курсів, що можуть використовуватися для професійної підготовки майбутніх менеджерів освіти або підвищення кваліфікації керівників закладів освіти. На платформі Coursera доступними є 68 курсів, на EdX - 19, на FutureLearn - 4, на Canvas.net -2 . Щодо змісту запропонованих курсів, вони є спрямованими на розвиток певних компетентностей, що дозволяють фахівцям у сфері управління закладами освіти успішно здійснювати професійну діяльність. До таких компетентностей належать: лідерська («Розвиток освітнього лідерства та управління» (Developing Your Educational Leadership and Management Vision), комунікативна («Лідерство і комунікація» (Leadership and Communication)), міжкультурна («Етичне лідерство» (Ethical Leadership)), конфліктна («Як стати успішним лідером» (Becoming an Effective Leader)), підприємницька («Управління інноваційною діяльністю» (Innovation Management)), управлінська («Керівництво організацією» (Organizational Leadership), «Трансформаційні зміни в освіті» (Leading Transformative Change in Education)), коучингова («Організаційні вміння: як керувати людьми» (Organizational Behavior: How to Manage People)) та ін.

Іноземні науковці (D. Glance, J. Headrick) одностайні в своїх судженнях, що проходження майбутніми менеджерами освіти масових відкритих онлайнкурсів дозволяє поглибити їхню обізнаність щодо різних напрямів здійснення професійної діяльності, удосконалити практичні навички та вміння, розширити їхній загальний кругозір та глибше усвідомити перспективи управлінської діяльності, мотивувати до постійного професійного саморозвитку [9; 11].

Висновки. Отже, проведені науково-теоретичні розвідки дозволяють зробити висновок, що підготовка майбутніх менеджерів освіти засобами неформальної освіти є сучасним світовим трендом, що має нормативно-правове підгрунтя. Так, у документах, прийнятих Європейською Комісією впродовж останніх десяти років, наголошено на визначальній ролі керівників в підвищенні якості освіти та необхідності інтегрування формальної та неформальної освіти. Популярність програм підготовки менеджерів освіти в умовах неформальної освіти зумовлена характером професійної діяльності 
таких фахівців, що вимагає постійного вивчення запитів суспільства щодо навчання та виховання молодого покоління та швидкого реагування на них. У більшості країн світу такі програми реалізуються через проведення тренінгів, участь у яких ініціюється самими майбутніми фахівцями. 3 еволюцією дистанційних форм навчання до засобів неформальної освіти віднесено також масові відкриті курси, що мають позитивний досвід запровадження в підготовку майбутніх менеджерів освіти в багатьох країнах світу.

\section{Лimepamypa:}

1. Про освіту : Закон України від 05 вересня 2017 p. № 2145-VIII. URL: https://zakon.rada.gov.ua/laws/show/2145-19 (дата звернення: 10.12.2021).

2. Самойленко О. МООС-платформи як інструмент інформальної освіти дорослих. Педагогічні науки : теорія, історія, інноващійні технологіï. 2019. № 4. C. 103-116. URL: https://repository.sspu.edu.ua/bitstream/123456789/7433/1/Samoilenko_MOOS-platformy.pdf (дата звернення: 15.12.2021)

3. Ткаченко В. П. Теоретичні основи підготовки фахівців 3 управління у галузі освіти. Педагогічні науки. 2017. Випуск 77(1). С. 175-181. URL: https://ps.journal.kspu.edu/index.php/ps/article/view/664 (дата звернення: 11.12.2021)

4. Bäckman E., Trafford B. Democratic Governance of Schools. Strasbourg : Council of Europe Publishing, 2007. 101 p.

5. Caza A., Brower H. Mentioning the Unmentioned : An Interactive Interview About the Informal Management Curriculum. Academy of Management Learning \& Education. 2014. Issue 14. P. 96-110. DOI: 10.5465/amle.2013.0164.

6. Communiqué of the Conference of European Ministers Responsible for Higher Education, Leuven and Louvain-la-Neuve. 2009. URL: http://europa.eu/rapid/press-release_IP-09675_en.ht (дата звернення: 10.12.2021).

7. Europe 2020 : A strategy for smart, sustainable and inclusive growth. COM(2010) 2020 final. Brussels : European Commission, 2010. URL: http://eur-lex.europa.eu/LexUriServ/ LexUriServ.do?uri=COM:2010:2020:FIN:EN:PDF (дата звернення: 10.12.2021).

8. European guidelines for validating non-formal and informal learning. 2015. URL: https://www.cedefop.europa.eu/en/publications/3073 (дата звернення: 10.12.2021).

9. Glance D., Forsey M., Riley M. The pedagogical foundations of massive open online courses. First Monday. 2013. Issue 18(5). DOI: 10.5210\%2Ffm.v18i5.4350

10. Graz Declaration - Forward from Berlin: the role of universities. 2003. URL: http://www.eua.be/eua/jsp/en/upload/COM_PUB_Graz_publication_final.1069326105539.pdf (дата звернення: 10.12.2021).

11. Headrick J. Leadership Education and MOOCs : A Content Analysis Approach to Understanding the Pedagogy and Characteristics of Leadership Massive Open Online Courses (MOOCs). University of Nebraska Lincoln, 2020. DOI: 10.13140/RG.2.2.10260.04481.

12. Rumbley L. E. Higher Education Leadership and Management Training : Global Maps and Gaps. International Higher Education. 2018. Issue 93. Pp. 4-6. DOI: 10.6017/ihe.2018.93.10368

13. The Education and Training (ET 2020) program of the European Commission. 2009. URL: https://education.ec.europa.eu/sites/default/files/document-library-docs/et2020_mandates 2018-2020_final.pdf (дата звернення: 10.12.2021).

\section{References:}

1. Pro osvitu: Zakon Ukrainy vid 05 veresnia 2017 r. № 2145-VIII [On Education : Law of Ukraine from the $5^{\text {th }}$ of September 2017 № 2145-VIII]. URL: https://zakon.rada.gov.ua/laws/show/214519 [in Ukrainian].

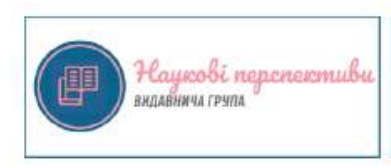


2. Samoilenko, O. (2019). MOOC-platformy yak instrument informalnoi osvity doroslykh [MOOC-platforms as a tool of informal education of adults]. Pedahohichni nauky: teoriia, istoriia, innovatsiini tekhnolohii - Pedagogical sciences: theory, history, innovation technologies, 4, 103116. URL: https://repository.sspu.edu.ua/bitstream/123456789/7433/1/Samoilenko_MOOSplatformy.pdf [in Ukrainian].

3. Tkachenko, V. (2017). Teoretychni osnovy pidhotovky fakhivtsiv z upravlinnia u haluzi osvity [Theretical foundation of training spesialists in the sphere of education management]. Pedahohichni nauky - Pedagogical sciences, 77(1), 175-181. URL: https://ps.journal.kspu.edu/ index.php/ps/article/view/664 [in Ukrainian].

4. Bäckman, E. \& Trafford, B. (2007). Democratic Governance of Schools. Strasbourg: Council of Europe Publishing [in English].

5. Caza, A. \& Brower, H. (2014).Mentioning the Unmentioned: An Interactive Interview About the Informal Management Curriculum. Academy of Management Learning \& Education, 14, 96-110. DOI: 10.5465/amle.2013.0164 [in English].

6. Communiqué of the Conference of European Ministers Responsible for Higher Education. (2009). Leuven and Louvain-la-Neuve. URL: http://europa.eu/rapid/press-release_IP-09675 en.ht [in English].

7. Europe 2020: A strategy for smart, sustainable and inclusive growth. COM(2010) 2020 final. (2010). Brussels: European Commission. URL: http://eur-lex.europa.eu/LexUriServ/ LexUriServ.do?uri=COM:2010:2020:FIN:EN:PDF [in English].

8. European guidelines for validating non-formal and informal learning. (2015). URL: https://www.cedefop.europa.eu/en/publications/3073 [in English].

9. Glance, D., Forsey, M., \& Riley, M. (2013). The pedagogical foundations of massive open online courses. First Monday, 18(5). DOI: 10.5210\%2Ffm.v18i5.4350 [in English].

10. Graz Declaration - Forward from Berlin: the role of universities. (2003). URL: http://www.eua.be/eua/jsp/en/upload/COM_PUB_Graz_publication_final.1069326105539.pdf [in English].

11. Headrick, J. (2020). Leadership Education and MOOCs: A Content Analysis Approach to Understanding the Pedagogy and Characteristics of Leadership Massive Open Online Courses (MOOCs). University of Nebraska Lincoln. DOI: 10.13140/RG.2.2.10260.04481 [in English].

12. Rumbley, L. E. (2018). Higher Education Leadership and Management Training: Global Maps and Gaps. International Higher Education, 93, 4-6. DOI: 10.6017/ihe.2018.93.10368 [in English].

13. The Education and Training (ET 2020) program of the European Commission. (2009). URL: https://education.ec.europa.eu/sites/default/files/document-library-docs/et2020_mandates_ 2018-2020_final.pdf [in English]. 